\title{
Pengaruh Variasi Waktu Penguapan Terhadap Kinerja Membran Selulosa Asetat pada Proses Ultrafiltrasi
}

\author{
(The Effect of Evaporation Time on Cellulose Acetate Membrane Performance \\ for Ultrafiltration Process)
}

\author{
Dewi Rara Amiyati, Dwi Indarti, Yeni Maulidah Muflihah \\ Jurusan Kimia, Fakultas Matematika dan Ilmu Pengetahuan Alam, Universitas Jember (UNEJ) \\ Jln. Kalimantan 37, Jember 68121 \\ E-mail:dwi.indarti@unej.ac.id
}

\begin{abstract}
Abstrak
Penelitian ini mempelajari pengaruh variasi waktu penguapan terhadap kinerja membran selulosa asetat. Pada proses ultrafiltrasi, selulosa asetat dibuat dengan menambahkan polietilen glikol (PEG) sebagai agen pembentuk pori membran dan meningkatkan nilai fluks membran. Pembuatan membran selulosa asetat dilakukan dengan metode inversi fasa. Variasi waktu penguapan yang digunakan selama $0,1,3$, dan 5 menit. Membran selulosa asetat yang terbentuk dikarakterisasi meliputi uji porositas, fluks dan rejeksi. Hasil penelitian menunjukkan waktu penguapan selama 5 menit menghasilkan membran yang lebih rapat. Hasil pengukuran porositas, fluks dan rejeksi terhadap dekstran $500 \mathrm{kDa}$ berturut-turut sebagai berikut: 53,35\%; 4,078 (L/jam. $\mathrm{m}^{2}$ ) dan 92,917\%.
\end{abstract}

Kata Kunci: Porositas, Selulosa Asetat, Waktu Penguapan.

\section{Abstract}

The effect of evaporation time on cellulose acetate membrane performance had been studied. Cellulose acetate membrane was prepared by adding polyethylene glycol (PEG) as a pore forming agent and improving the flux of membrane. Preparation of cellulose acetate membrane based on phase inversion method. Variation of evaporation time is $0,1,3$, and 5 minute. Characterization of cellulose acetate membranes include porosity, flux and rejection. The result showed that evaporation time during 5 minutes has tightest pores. The result of measurement of porosity, flux and rejection of dextran $500 \mathrm{kDa}$ were obtained as follows respectively: $53,35 \% ; 4,078\left(\mathrm{~L} / \mathrm{jam} . \mathrm{m}^{2}\right)$ dan $92,917 \%$.

Keywords: Porosity, Cellulose acetate, evaporation time.

\section{PENDAHULUAN}

Membran ultrafiltrasi merupakan salah satu jenis membran dengan gaya dorong tekanan yang digunakan untuk memisahkan makromolekul dan koloid dari larutannya. Membran ultrafiltrasi mempunyai struktur asimetrik dengan lapisan atas lebih rapat (ukuran pori lebih kecil) dan porositas permukaan lebih rendah dibanding lapisan bawah, sehingga ketahanan hidrodinamiknya lebih tinggi. Ukuran molekul yang dapat ditahan oleh membran ultrafiltrasi berkisar antara $10^{3}-10^{8}$ Dalton [1].

Proses pembuatan membran ultrafiltrasi sering kali menggunakan teknik inversi fasa, yaitu suatu proses pengubahan bentuk polimer dari fasa cair menjadi padatan dengan kondisi terkendali. Membran dapat dibuat dari berbagai material seperti selulosa asetat (CA), polisulfon, polieter sulfon, dan poliamida [2]. Pemilihan material membran menjadi penting karena berhubungan dengan pemilihan jenis pelarut dan nonpelarut yang digunakan. Material membran ultrafiltrasi yang berkembang saat ini adalah membran selulosa asetat.

Pembuatan membran selulosa asetat biasanya dilakukan dengan penambahan aditif yang dimaksudkan untuk mengatur viskositas larutan polimer, memperbanyak jumlah pori yang terbentuk atau untuk merubah sifat polimer dari hidropobik menjadi hidrofilik. Aditif yang dapat ditambahkan ke dalam proses pembuatan membran selulosa asetat antara lain polivinil klorida, dimetil ftalat, monosodium glutamat dan polietilen glikol. Penambahan polietilen glikol (PEG) sebagai aditif dapat meningkatkan laju permeasi membran [3] karena PEG berfungsi sebagai agen pembentuk pori membran. Peningkatan konsentrasi aditif (PEG 600) ke dalam larutan casting mampu meningkatkan fluks dari 15,8 L/jam. ${ }^{2}$ menjadi 85,1 L/jam. $\mathrm{m}^{2}$ tetapi menurunkan rejeksi protein dari $96 \%$ menjadi 77\% [4]. Penambahan aditif (PEG 600) 5\% dapat menghasilkan fluks sebesar 234,64 L/jam.m ${ }^{2}$ dan rejeksi garam sebesar 81,5\% [5].

Parameter lain yang dapat mempengaruhi proses pembentukan struktur membran yang dihasilkan adalah waktu penguapan pelarut. Waktu penguapan pelarut secara jelas mengindikasikan bahwa semakin lama waktu penguapan akan mempertebal permukaan membran dan menurunkan fluks air tetapi meningkatkan selektivitas membran [6]. Pembuatan membran selulosa asetat dengan waktu penguapan 3 menit dengan komposisi $22 \%$ selulosa asetat, $15 \%$ aseton, $60 \%$ dimetil sulfoksida (DMSO), dan 3\% dimetil ftalat (DMP) menghasilkan membran ultrafiltrasi dengan nilai fluks $2,2438 \mathrm{~L} / \mathrm{jam} . \mathrm{m}^{2}$ dan rejeksi terhadap dekstran 100-200 kDa sebesar 91,15\% [7]. 
Penelitian ini difokuskan pada pembuatan membran selulosa asetat dengan pelarut aseton dan DMSO serta penambahan PEG sebanyak 5\% dari total larutan polimer. Variasi waktu penguapan yang digunakan $0,1,3$, dan 5 menit kemudian dikaji pengaruhnya terhadap porositas, fluks, koefisien permeabilitas dan rejeksi terhadap deksran $500 \mathrm{kDa}$.

\section{METODE PENELITIAN}

\section{Alat Penelitian}

Satu set alat ultrafiltrasi modul flat sistem dead-end, magnetik stirer, plat kaca, selotip, lampu neon, stopwatch, kompresor, piknometer, labu ukur $25 \mathrm{~mL}, 50 \mathrm{~mL}$ dan 1000 $\mathrm{mL}$, pipet mohr $1 \mathrm{~mL}, 5 \mathrm{~mL}$ dan $10 \mathrm{~mL}$, pipet volume $1 \mathrm{~mL}$ dan $5 \mathrm{~mL}$, ball pipet, gelas ukur $10 \mathrm{~mL}$ dan $50 \mathrm{~mL}$, gelas beker $100 \mathrm{~mL}$, bak koagulasi, neraca analitik, botol semprot, gunting, spektrofotometer UV-Vis model 752.

\section{Bahan Penelitian}

Selulosa asetat $(\mathrm{BM}=30 \mathrm{kDa})$, aseton; $\rho=0,79 \mathrm{~g} / \mathrm{mL}$, dimetil sulfoksida (DMSO); $\rho=1,11 \mathrm{~g} / \mathrm{mL}$ ), akuades, dimetil Ptalat (DMP); $\rho=1.19 \mathrm{~g} / \mathrm{mL}$, Polietilen glikol (PEG) $600 \mathrm{Da} ; \rho=1,12 \mathrm{~g} / \mathrm{mL}$, dekstran $500 \mathrm{kDa}$, fenol; $\rho=1,057$ $\mathrm{g} / \mathrm{mL}, \mathrm{H}_{2} \mathrm{SO}_{4} ; \rho=1,84 \mathrm{~g} / \mathrm{mL}$, kertas saring dan alumunium foil.

\section{Prosedur Penelitian}

\section{Pembuatan Membran Selulosa Asetat}

Membran selulosa asetat dibuat dengan melarutkan selulosa asetat sebanyak 2,74 gram dalam 2,3 mL pelarut aseton, 6,8 mL DMSO dan 0,5 mL DMP serta ditambahkan aditif PEG sebanyak $0,68 \mathrm{~mL}$. Larutan polimer dengan magnetik stirrer selama 4 jam sampai homogen. Larutan yang sudah homogen didiamkan selama 4 jam untuk menghilangkan gelembung udaranya. Larutan polimer yang tidak mengandung gelembung udara dicetak di atas plat kaca dan dibiarkan di udara terbuka dengan variasi waktu penguapan $0,1,3$ dan 5 menit. Film membran dicelupkan dalam bak koagulasi hingga terjadi pemadatan membran.

\section{Karakterisasi Membran Selulosa Asetat}

Karakterisasi membran selulosa asetat meliputi uji porositas, penentuan waktu kompaksi, fluks air, koefisien permeabilitas dan rejeksi.

\section{Uji Porositas}

Porositas membran dihitung dengan menentukan perbandingan volume pori terhadap volume total membran berdasarkan persamaan berikut [8]:

$$
\begin{aligned}
& P(\%)=\frac{w_{1}-w_{2}}{\rho_{w} \cdot V_{T}} \times 100 \% \\
& \text { dimana } \quad V_{T}=\frac{w_{1}-w_{2}}{\rho_{w}}+\frac{w_{2}}{\rho_{m d}} \\
& \text { keterangan : } \\
& w_{1}=\text { berat basah membran }(\mathrm{g}) \\
& w_{2}=\text { berat kering membran }(\mathrm{g}) \\
& \rho_{w}=\text { densitas air }\left(\mathrm{g} / \mathrm{cm}^{3}\right) \\
& V_{T}=\text { volume membran basah }\left(\mathrm{cm}^{3}\right) \\
& \rho_{m d}=\text { densitas membran kering }\left(\mathrm{g} / \mathrm{cm}^{3}\right)
\end{aligned}
$$

\section{Uji Fluks Air}

Fluks air diperoleh dengan mengukur banyaknya volume air yang melewati membran tiap satuan luas permukaan membran dan satuan waktu. Sebelum uji flluks, dilakukan penentuan waktu kompaksi terlebih dahulu. Penentuan waktu kompaksi dilakukan dengan mengalirkan air dalam alat ultrafiltrasi dengan mengamati waktu yang diperlukan tiap $1 \mathrm{~mL}$ permeat hingga diperoleh waktu konstan. Fluks volume dinyatakan sebagai berikut :

$$
J_{v}=\frac{V}{A \cdot t}
$$

di mana :

$$
\begin{aligned}
J_{V} & =\text { fluks air }\left(\mathrm{L} / \mathrm{jam} . \mathrm{m}^{2}\right) \\
\mathrm{V} & =\text { volume air }(\mathrm{L}) \\
\mathrm{A} & =\text { luas permukaan }\left(\mathrm{m}^{2}\right) \\
\mathrm{t} & =\text { waktu }(\mathrm{jam})
\end{aligned}
$$

\section{Uji Koefisien Permeabilitas}

Koefisien permeabilitas membran ditentukan dengan mengukur fluks air dengan variasi tekanan $1 ; 1,5 ; 2 ; 2,5$; dan 3 bar selama 1 jam. Nilai fluks untuk setiap tekanan pada masing-masing membran dibuat grafik antara nilai tekanan (sumbu X) dengan nilai fluks (sumbu Y). Nilai koefisien permeabilitas $\left(\mathrm{L}_{\mathrm{p}}\right)$ ditentukan dari nilai slope yang didapatkan pada setiap grafik. Permeabilitas ditentukan dengan persamaan [1]:

$$
J_{v}=L_{p} \cdot \Delta P
$$

\section{Uji Rejeksi}

Penentuan rejeksi membran dilakukan menggunakan dekstran $500 \mathrm{kDa}$ dengan konsentrasi 1000 ppm sebagai larutan umpannya. Penentuan rejeksi membran dilakukan setelah proses scanning pada panjang gelombang 400-500 nm. Penentuan kurva kalibrasi dilakukan pada panjang gelombang optimum larutan standart dekstran $500 \mathrm{kDa}$ $1000 \mathrm{ppm}$. Larutan standart maupun sampel diambil $1 \mathrm{~mL}$ dan ditambahkan masing-masing $1 \mathrm{~mL}$ fenol $5 \%$ dan $5 \mathrm{~mL}$ $\mathrm{H}_{2} \mathrm{SO}_{4}$ kemudian diukur absorbansinya pada panjang gelombang 400-550 nm. Rejeksi dihitung dengan persamaan berikut [1]:

$$
R=\left(1-\frac{C_{p}}{C_{f}}\right) \times 100 \%
$$

di mana:

$\mathrm{R}=$ nilai koefisien rejeksi $(\%)$

$\mathrm{C}_{\mathrm{p}}=$ konsentrasi permeat (ppm)

$C_{f}=$ konsentrasi larutan umpan (ppm)

\section{HASIL DAN PEMBAHASAN}

\section{Membran Selulosa Asetat}

Membran selulosa asetat dibuat dengan teknik inversi fasa. Waktu penguapan pelarut akan mempengaruhi proses pembentukan struktur membran yang dihasilkan. Waktu penguapan pelarut yang semakin lama akan mempertebal permukaan membran dan memperkecil pori membran. Penambahan aditif PEG pada penelitian ini merupakan salah satu usaha dalam rangka memperbaiki kinerja membran. Penambahan PEG sebagai aditif pada membran dimaksudkan untuk memperbanyak pori membran sehingga dapat meningkatkan fluks yang dihasilkan. PEG yang 
ditambahkan sebanyak 5\% w/w dari total larutan polimer. Tabel 1. Sifat fisik membran selulosa asetat

\begin{tabular}{lll}
\hline Waktu penguapan & Ketebalan $(\mathrm{mm})$ & Warna \\
\hline 0 menit & 0.052 & Putih \\
\hline 1 menit & 0.058 & Putih \\
\hline 3 menit & 0.068 & Putih \\
\hline 5 menit & 0.074 & Putih \\
\hline
\end{tabular}

Membran selulosa asetat yang dihasilkan berwarna putih dengan ketebalan yang berbeda (Tabel 1). Waktu penguapan yang semakin lama akan mempertebal permukaan membran yang dihasilkan. Waktu penguapan yang semakin lama akan mengalami proses delayed demixing di mana pelarut akan lebih tertahan di dalam membran sehingga proses presipitasi antara pelarut dan nonpelarut berjalan lambat dan sebagai hasilnya akan diperoleh membran yang semakin tebal.

\section{Pengaruh Waktu Penguapan Pelarut Terhadap Porositas Membran}

Porositas membran merupakan perbandingan antara volume pori dengan volume total membran. Nilai porositas membran sebagai fungsi dari waktu penguapan terhadap porositas membran dapat dilihat pada Gambar 1. Semakin lama waktu penguapan yang diberikan, maka porositasnya semakin kecil. Waktu penguapan yang semakin lama, dihasilkan membran yang semakin tebal. Ketebalan membran akan mempengaruhi volume dan densitas membran yang dihasilkan. Waktu penguapan yang semakin lama menghasilkan densitas yang semakin besar yang mengindikasikan membran yang dihasilkan semakin rapat sehingga kemampuan molekul air untuk masuk ke dalam membran menjadi kecil. Hal inilah yang menyebabkan porositasnya menjadi semakin kecil.

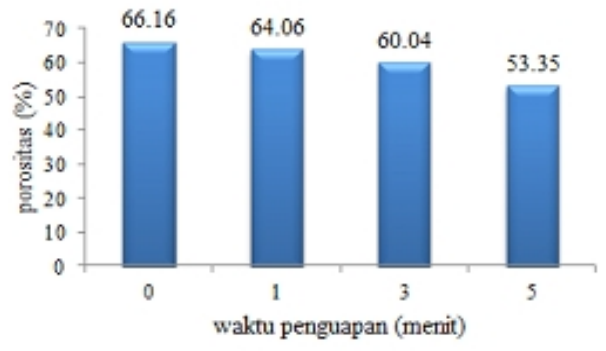

Gambar 1. Nilai porositas membran selulosa asetat terhadap waktu penguapan

\section{Pengaruh Waktu Penguapan Pelarut Terhadap Nilai} Fluks

Pengukuran kinerja fluks membran dilakukan dengan alat filtrasi dead end dengan melakukan proses kompaksi terlebih dahulu pada membran yang akan diuji. Proses kompaksi dilakukan untuk mengkondisikan pori-pori membran dalam geometri dan ukuran yang tetap selama proses filtrasi dengan tekanan tertentu sehingga nilai fluksnya konstan.

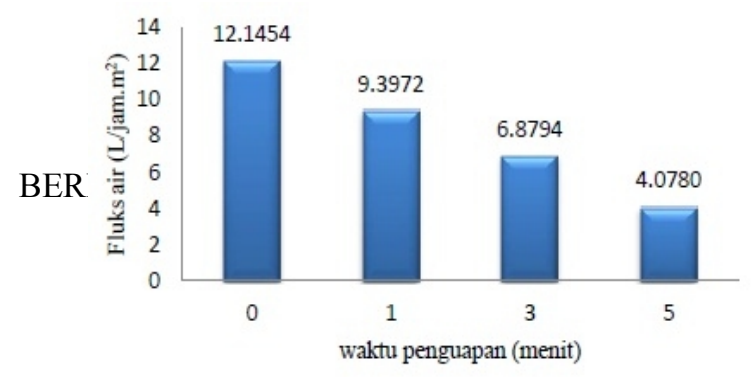

Gambar 2. Nilai fluks air membran selulosa asetat

Nilai fluks air (Gambar 2) menunjukkan waktu penguapan yang semakin lama, fluks yang dihasilkan semakin kecil. Penurunan fluks ini dikarenakan porositas yang dihasilkan semakin kecil yang mengindikasikan pori membran semakin rapat akibatnya fluks yang dihasilkan semakin menurun.

\section{Pengaruh Waktu Penguapan Pelarut Terhadap Koefisien Permeabilitas}

Koefisien permeabilitas adalah kemampuan suatu membran untuk dilewati suatu spesi per satuan tekanan. Nilai koefisien diambil dari gradien hubungan fluks terhadap tekanan melalui titik $(0,0)$. Koefisien permeabilitas membran (Gambar 3) yang dihasilkan menurun seiring bertambahnya waktu penguapan. Penurunan ini disebabkan karena waktu penguapan pelarut yang semakin lama akan menghasilkan porositas yang semakin kecil. Porositas yang semakin kecil akan memberikan nilai fluks yang semakin rendah karena pori yang ada pada membran semakin rapat memungkinkan molekul air sulit menembus membran. Fluks berbanding lurus dengan nilai koefisien permeabilitas yang dihasilkan. Oleh karena itu, nilai koefisien permeabilitas yang dihasilkan semakin rendah.

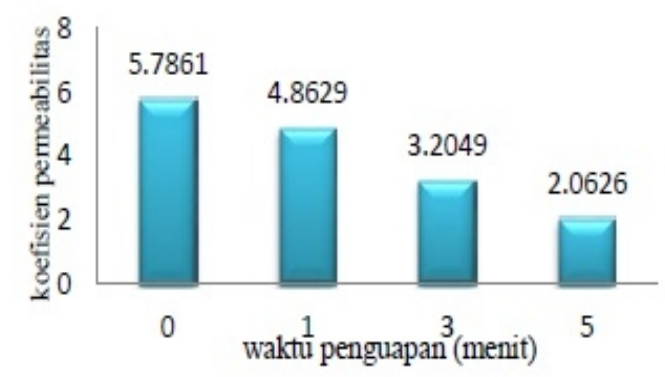

Gambar 3. Nilai koefisien permeabilitas membran selulosa asetat

\section{Pengaruh Waktu Penguapan Pelarut Terhadap Rejeksi} Dekstran

Rejeksi merupakan ukuran selektivitas membran untuk meloloskan atau menahan suatu molekul. Penentuan rejeksi membran dilakukan setelah proses scanning. Scanning dilakukan pada panjang gelombang 400-550 nm dan dari scanning panjang gelombang tersebut diperoleh nilai absorbansi optimum pada panjang gelombang $492 \mathrm{~nm}$

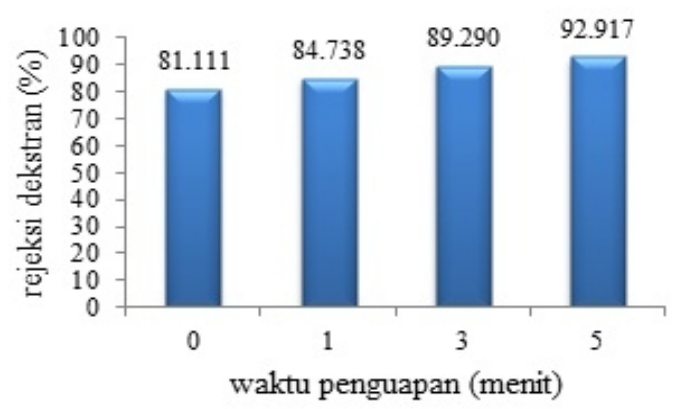

Gambar 4. Nilai koefisien rejeksi membran selulosa asetat terhadap waktu penguapan 
Koefisien rejeksi dekstran $500 \mathrm{kDa}$ (Gambar 4) yang dihasilkan cenderung meningkat seiring dengan bertambahnya waktu penguapan. Peningkatan ini disebabkan karena semakin lama waktu penguapan pelarut, porositas yang dihasilkan semakin kecil yang mengindikasikan pori membran semakin rapat sehingga kemampuan molekul dekstran $500 \mathrm{kDa}$ untuk melewati membran menjadi lebih sulit. Akibatnya, banyak molekul dekstran $500 \mathrm{kDa}$ yang lebih tertahan oleh membran sehingga koefisien rejeksinya menjadi meningkat.

Penelitian dengan komposisi yang sama [7] tanpa penambahan PEG, hasil kinerja uji fluks dan koefisien permeabilitas yang diperoleh lebih rendah dari hasil penelitian ini. Hal ini dimungkinkan karena pada penelitian ini ada penambahan aditif PEG yang ditujukan untuk memperbanyak pori membran. Hasil uji kinerja rejeksinya pada penelitian ini digunakan dekstran dengan berat molekul $500 \mathrm{kDa}$ sebagai larutan umpannya menghasilkan rejeksi sebesar 89,290\% saat waktu penguapan 3 menit dan sebesar $92,917 \%$ saat waktu penguapan 5 menit, sedangkan pada penelitian sebelumnya [7] digunakan dekstran dengan berat molekul 100-200 kDa menghasilkan rejeksi sebesar 91,15\% saat waktu penguapan 3 menit dan sebesar 92,18\% saat waktu penguapan 4 menit. Dektran dengan berat molekul yang lebih tinggi semestinya mampu menghasilkan rejeksi yang lebih tinggi karena berat molekul yang tinggi akan lebih sulit untuk melewati membran. Penurunan ini kemungkinan disebabkan karena adanya penambahan aditif PEG yang tidak hanya dapat memperbanyak pori membran tetapi juga dapat memperbesar pori membran.

\section{KESIMPULAN}

Variasi waktu penguapan mempengaruhi porositas membran yang dihasilkan. Semakin lama waktu penguapan, porositas yang dihasilkan semakin rendah. Nilai fluks membran semakin kecil seiring bertambahnya waktu penguapan pelarut tetapi meningkatkan rejeksi membran terhadap dekstran $500 \mathrm{kDa}$.

\section{UCAPAN TERIMA KASIH}

Ucapan terima kasih disampaikan pada Bapak Dr. Bambang Piluharto, S.Si., M.Si dan Bapak Drs. Zulfikar, Ph.D yang telah memberikan kritik dan saran demi penyempurnaan penelitian ini.

\section{DAFTAR PUSTAKA}

[1] Mulder, M. 1996. Basic Principles of Membrane Technology, 2nd ed. Dorddercht : Kluwer Academic Publishers.

[2] Wenten, I ,G. 2000. Teknologi Membran Industrial. Bandung: Penerbit ITB.

[3] Saljoughi, E. 2010. "Effect of PEG additive and coagulation bath temperature on the morphology permeability and thermal/chemical stability of asymmetric CA membranes", Desalination Vol 262 (1-3): 72-78.

[4] Krishnamoorthy, L. Arif, P. M. and Ahmedkhan, R. 2010. "Separation of Proteins from Aqueous Solution
Using Cellulose Acetate/Poly (Vinyl Chloride) Blend Ultrafiltration Membrane", J Mater Sci Vol 46 (2): 2914-2921.

[5] Waheed, Ahmad, Khan, Gul, Jamil, Islam, and Hussain. 2014. "Synthesis, Characterization, Permeation and Antibacterial Properties of Cellulose Acetate/Polyethylene Glycol Membranes Modified with Chitosan", Desalination Vol 351 (2): 59-69.

[6] Bhongsuwan, D. and T, Bhongsuwan. 2008. "Preparation of cellulose acetate membranes for ultranano-filtrations", Kasetsart J. Nat. Sci Vol 42 (2): 311-317.

[7] Kartika, L. 2010. Pemisahan Surfaktan Anionik Sodium Dodesil Sulfat (SDS) dengan menggunakan Membran Ultrafiltrasi Selulosa Asetat (CA). Tidak dipublikasikan. Skripsi. Jember: Universitas Jember.

[8] Velu, S. Muruganandam, L. and Arthanareeswaran, G. 2015. "Preparation and Performance Studies on Polyethersulfone Ultrafiltration Membranes Modified with Gelatin for Treathment of Tannery and Distillery Wastewater", Brazilian Journal of Chemical Engineering Vol 32 (01): 79-189. 